\title{
MENINGKATKAN AKTIVITAS FISIK ANAK-ANAK AUTIS MELALUI PEMBELAJARAN OLAHRAGA DI TAMAN KANAK-KANAK
}

\author{
Rini Ros Mardianah ${ }^{1}$, Ade Vindyastuti ${ }^{2}$, Ema Aprianti \\ ${ }^{1}$ IKIP Siliwangi, Jalan Terusan Jenderal Sudirman Cimahi \\ ${ }^{2}$ IKIP Siliwangi, Jalan Terusan Jenderal Sudirman Cimahi \\ ${ }^{3}$ IKIP Siliwangi, Jalan Terusan Jenderal Sudirman Cimahi \\ ${ }^{1}$ rini.rosmardianah@yahoo.co.id, ${ }^{2}$ adevindyastuti@yahoo.com, ${ }^{3}$ emaaprianti88@gmail.com
}

\begin{abstract}
The research is based on the physical diversity of early childhood who have different background. The purpose of this research is to know the condition of physical activity development of autistic children in kindergarten through sports learning, to know the procedure and process of exercise learning to increase physical activity of autistic children in kindergarten, and to know the results of implementation of the implementation of sports learning for children with autism in kindergarten. The formulation of the problem in this research is how the application of sports learning in increasing the physical activity of autistic children. The research method used is classroom action research method. The results showed that with the learning of sports can increase the physical activity of autistic children in kindergarten by 63\% and children of autism kindergarten more able to explore his gestures well. The recommendation of this research is the need for the provision of facilities and infrastructure to support the physical activity of autistic children, the need to develop the ability of the exploration of physical movement, and the need to apply sports learning in children with autism in kindergarten.
\end{abstract}

Keywords: physical activity, sports learning, autism child, kindergarten

\begin{abstract}
Abstrak
Penelitian yang dilakukan dilandasi keberagaman fisik anak usia dini yang memiliki latar belakang yang berbeda. Tujuan penelitian dalam artikel ini adalah untuk mengetahui kondisi perkembangan aktivitas fisik anak-anak autis di Taman Kanak-kanak melalui pembelajaran olahraga, untuk mengetahui tata cara dan proses pelaksanaan pembelajaran olahraga untuk meningkatkan aktivitas fisik anak-anak autis di Taman kanak-kanak, dan untuk mengetahui hasil pelaksanaan penerapan pembelajaran olahraga bagi anak autis di Taman Kanak-kanak. Rumusan masalah dalam penelitian ini adalah bagaimana penerapan pembelajaran olahraga dalam meningkatkan aktivitas fisik anak-anak autis. Metode penelitian yang digunakan adalah metode penelitian tindakan kelas. Hasil penelitian menunjukkan bahwa dengan pembelajaran olahraga dapat meningkatkan aktivitas fisik anak-anak autis Taman Kanak-kanak sebesar 63\% dan anak-anak autis Taman Kanak-kanak lebih bisa mengeksplorasi gerak tubuhnya secara baik. Rekomendasi penelitian ini adalah perlunya penyediaan sarana dan prasarana untuk menunjang aktivitas fisik anak autis, perlunya mengembangkan kemampuan eksplorasi gerak fisik, dan perlunya menerapkan pembelajaran olahraga pada anak-anak autis di Taman Kanak-kanak.
\end{abstract}

Kata Kunci: aktivitas fisik, pembelajaran olahraga, anak autis, Taman Kanak-kanak.

How to Cite: Mardianah1, R. M., VIndyastuti2, A., Aprianti, E. (2018). Meningkatkan Aktivitas Fisik Anak-Anak Autis Melalui Pembelajaran Olahraga Di Taman Kanak-Kanak. Ceria, 1 (3), 30-36. 


\section{PENDAHULUAN}

Penelitian yang dilakukan dilandasi keberagaman fisik anak usia dini yang memiliki latar belakang yang berbeda, karena pada dasarnya pertumbuhan morfologi dan psikis anak dipengaruhi oleh lingkungan, orang tua dan teman sepermainan anak usia dini. Firmansyah, (2018) mengemukakan pengaruh tumbuh kembang anak secara psikologi dapat berdampak pada kemampuan motorik dan fisik anak.

Autisme adalah gangguan perkembangan yang muncul selama tiga tahun pertama kehidupan dan ditandai oleh masalah komunikasi, defisit interaksi sosial dan minat dan perilaku berulang atau terbatas. Meskipun kriteria diagnosis gangguan spektrum autistik tidak melibatkan ketidakmampuan untuk menutupi keterampilan motorik, penelitian menunjukkan bahwa defisit motorik dan keterlambatan pada anak-anak dengan autisme adalah mungkin (Yanardag, Yilmaz, \& Aras, 2010).

Olahraga berguna karena dapat mengurangi kegagalan motorik dan menyediakan integrasi sosial. Namun, meskipun efeknya sangat bermanfaat, aktivitas fisik melalui pembelajaran olahraga tidak cukup diberikan untuk anak-anak autis, namun perlu diamati oleh keluarga, guru, dan spesialis lain untuk mengetahui beberapa kesulitan dalam menyesuaikan aktivitas fisik dalam kegiatan kehidupan sehari-hari anak-anak autis. Artikel ini berfokus pada jenis kegiatan pembelajaran olahraga apa yang dapat diperkenalkan kepada anak-anak autis pada usia tertentu dan menentukan strategi yang mungkin diikuti dan langkah-langkah apa saja yang dapat diadopsi (Marta, 2017).

Autisme atau gangguan autistik didefinisikan sebagai kegagalan perkembangan merupakan salah satu kategori gangguan spektrum autistik atau gangguan perkembangan pervasive. Autisme yang muncul selama 3 tahun pertama kehidupan dicirikan oleh masalah komunikasi dan interaksi sosial, dan perilaku/minat yang terbatas/berulang (Doyle \& Iland, 2004). Autisme adalah salah satu cacat perkembangan termasuk dalam kategori gangguan perkembangan pervasive. Gangguan ini termasuk kategori sub dari gangguan spektrum autistik seperti sindrom asperger, sindrom rett, autisme khas, dan gangguan disintegratif masa kanak-kanak. Di bawah ini adalah fitur umum yang digambarkan sebagai kriteria diagnostik untuk anak-anak autis (Association, 2000). Gangguangangguan tersebut sebagai berikut: a. Kegagalan dalam penggunaan perilaku nonverbal seperti kontak mata, gerak tubuh dan mimik, dan postur tubuh; $b$. Penurunan nilai dalam mengembangkan hubungan teman sebaya yang sesuai dengan tingkat perkembangan; c. Kurangnya keinginan spontan untuk berbagi kesenangan, minat, atau pencapaian dengan orang lain; $d$. Kegagalan timbal balik sosial atau emosional.

Penurunan dalam komunikasi dimanifestasikan oleh hal-hal sebagai berikut: a. Keterlambatan, atau kurangnya perkembangan bahasa lisan secara total; ketidakmampuan untuk mengucapkan sepatah kata pun dalam usia 2 tahun, dan frasa sederhana dengan dua kata dalam usia 3 tahun; $b$. Penurunan nilai dalam kemampuan untuk memulai atau mempertahankan percakapan dengan individu lain dengan penyampaian yang memadai; $c$. Penggunaan bahasa berulang atau bahasa idiosynkratik; d. Pembatasan pada permainan sosial atau permainan simbolik yang sesuai dengan tingkat perkembangan.

Sementara itu, minat dan perilaku yang dibatasi/berulang menunjukkan beberapa hal berikut ini: a. Kepentingan 


\section{JURNAL CERIA}

ISSN : 2614-6347 (Print) 2614-4107 (Online)

Vol.1 1 No.3 1 Mei 2018

yang intensif dan abnormal; b. Ketat mengikuti rutinitas atau ritual tertentu yang tidak berfungsi; c. Perilaku motorik stereotip dan berulang (misalnya mengepakkan tangan, memutar gerakan seluruh tubuh dan bergoyang-goyang); d. Keasyikan terusmenerus dengan bagian-bagian objek.

Untuk diagnosis autisme, seorang anak harus mempertahankan setidaknya enam dari 12 ciri yang disebutkan sebelumnya, termasuk setidaknya dua dari bagian pertama, setidaknya satu dari bagian kedua, dan setidaknya satu dari bagian ketiga. Selain itu, salah satu ciri harus dilihat dan dimiliki sebelum 36 bulan pertama (Association, 2000). Selain keenam ciri ini, fluktuasi perilaku juga harus dilihat pada anak yang seharusnya memiliki autisme.

Beberapa disorientasi dan masalah dalam aktivitas kehidupan sehari-hari terlihat pada autisme, seperti agresi yang ditampilkan kepada diri sendiri atau lingkungan, kesulitan nutrisi, gangguan tidur, dan masalah toilet. Selain itu, salah satu dasar melumpuhkan pada anak-anak autisme adalah pembatasan intelektual. Hampir 75 persen dari semua orang dengan autisme mungkin mengalami kesulitan belajar (Bryson, Bradley, Thompson, \& Wainwright, 2008).

Dikarenakan ciri-ciri anak-anak seperti kesulitan bergerak dan integrasi sosial, kegagalan komunikasi, minat dan aktivitas berulang/ terbatas, anak-anak dengan autisme tidak dapat bermain dengan teman sebaya dan berpartisipasi dalam kegiatan fisik dan berbagai cabang olahraga, maka penelitian dalam artikel ini mencoba sesuatu yang lain yaitu menerapkan pembelajaran olahraga untuk meningkatkan aktivitas fisik mereka. Diharapkan dengan aktivitas fisik yang meningkat, aktivitas-aktivitas lainnya juga meningkat (kognitif dan afektifnya).

Artikel ini berfokus pada penghapusan kesulitan yang dialami oleh spesialis dan keluarga selama aplikasi, strategi, dan tindakan pencegahan melalui perspektif pendidikan khusus. Selain itu, contoh cabang olahraga dan resep kegiatan untuk berbagai artikel ini berfokus pada penghapusan kesulitan yang dialami selama ini. Cabang olahraga dan resep kegiatan untuk berbagai kelompok usia anak-anak dengan autisme akan dijelaskan.

Beberapa kegiatan tersebut yaitu: pushup, sit-up, chin-up, dan melompat pada trampolin untuk anak-anak dengan autism (Kurtz, 2008; Moor, 2008). Perencanaan fisik adalah kemampuan untuk membuat konsep rencana, dan melakukan tugas fisik motorik atau urutan fisik motor yang tidak biasa. Agar dapat menjalankan rencana fisik motorik dengan baik, anak autis harus menyadari apa yang akan terjadi ketika dia melakukan aktivitas fisiknya. Keterampilan ini dapat ditingkatkan dengan permainan dan kegiatan seperti memindahkan beras, menggali pasir atau dempul untuk menemukan bendabenda kecil yang tersembunyi; menebak tekstur atau bentuk dengan mata tertutup. Selain itu, menghindar dari bola, tetherball atau bulu tangkis adalah kegiatan-kegiatan lain yang bermanfaat untuk membantu dalam mengajar motorplanning untuk anak-anak autis (Kurtz, 2008; Moor, 2008).

\section{METODE}

Metode penelitian yang digunakan adalah metode penelitian tindakan kelas. Penelitian tindakan kelas dilaksanakan selama 4 bulan, dari Januari sampai dengan April 2018. Subyek penelitiannya anak didik sebanyak 27 orang.

Metode pengumpulan data yang digunakan adalah observasi dengan instrumen berupa daftar cek, dokumentasi dan kepustakaan. Setelah pengetesan tahap awal dilaksanakan, 


\section{JURNAL CERIA}

ISSN : 2614-6347 (Print) 2614-4107 (Online)

Vol.1」No.3 $\mid$ Mei 2018

dapat diketahui kemampuan awal aktivitas fisik anak-anak autis melalui pembelajaran olahraga, kemudian dilanjutkan dengan rencana perbaikan pada siklus I yang dilaksanakan sebanyak 3 kali pertemuan.

Apabila pada siklus I peningkatan aktivitas fisik anak-anak autis minimal $60 \%$ belum terpenuhi, maka dilanjutkan pada siklus ke II dengan 3 kali pertemuan minimum mencapai target 60\%. Apabila pada siklus II peningkatan aktivitas fisik terpenuhi maka penelitian dinyatakan selesai (Arikunto, 2009, 2010; Sudjana, 2009; Sugiyono, 2008). Pelaksanan tindakan kelas ini dilakukan perencanaan, observasi dan refleksi dengan alur pelaksanaan tindakan seperti berikut:

Gambar 1. Alur Pelaksanaan Tindakan

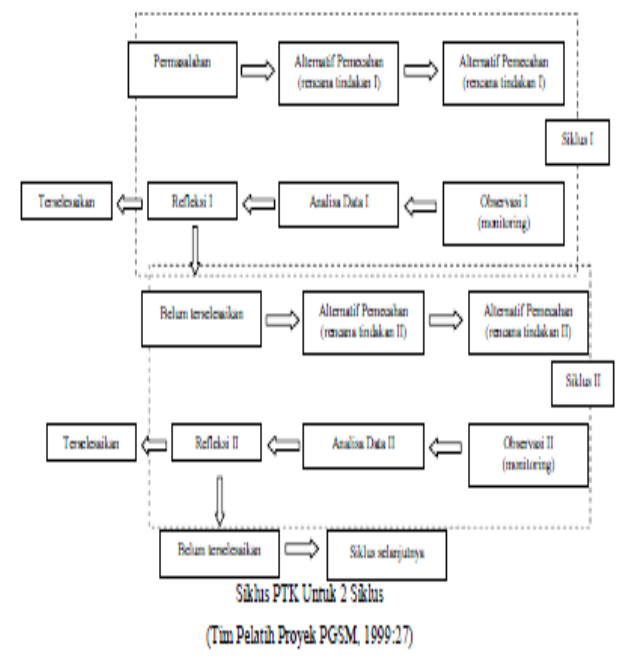

\section{HASIL DAN PEMBAHASAN}

Penelitian dilakukan pada anak-anak autis Taman Kanak-Kanak yang berjumlah 27 orang anak yang terdiri dari 11 orang laki-laki dan 16 orang perempuan. Melalui pembelajaran olahraga, anak-anak autis dapat meningkatkan aktivitas fisiknya secara bebas dan mandiri.

Pelaksanaan tindakan pada siklus I didapatkan hasil 24 anak masih belum berkembang atau dipresentasikan

sebesar 89\%, 1 anak sudah mulai berkembang atau sebesar $4 \%$, belum ada peningkatan anak sesuai dengan harapan dan berkembang sangat baik sehingga proses siklus dilanjutkan ke siklus II. Penilaian siklus I pada pertemuan pertama digambarkan melalui grafik berikut ini:

Grafik 1. Penilaian siklus I penerapan pembelajaran olahraga terhadap aktivitas fisik anak-anak autis di Taman Kanak-kanak.

\section{Penilaian Siklus I Pertemuan Pertama}

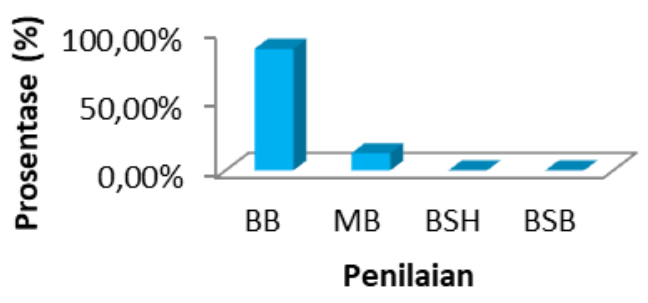

Penelitian pada siklus I masih didapatkan banyak anak yang masih tidak mengikuti pembelajaran olahraga secara aktif, kemudian dilakukan perbaikan perencanaan pada siklus II dengan perencanaan yang lebih baik. Setelah perencanaan dibuat berdasarkan diskusi para guru, maka dilaksanaan tindakan pada siklus II dengan 3 kali pertemuan. Melihat hasil yang didapatkan dan analisa lapangan didapatkan peningkatan aktivitas fisik anak-anak autis melalui pembelajaran olahraga diperoleh 3 orang anak belum berkembang dengan persentase sebesar $11 \%$. Anak yang mulai berkembang sebanyak 15 orang anak dengan persentase sebesar $67 \%$, dan anak yang sudah berkembang sesuai harapan sebanyak 9 anak dengan persentase sebesar 33\%.

Pelaksanaan pada siklus II dilakukan melalui diskusi dan perbaikan perencanaan berdasarkan kelemahan dan keterbatasan waktu. Peneliti segera 


\section{JURNAL CERIA}

ISSN : 2614-6347 (Print) 2614-4107 (Online)

Vol.1 1 No.3 1 Mei 2018

berdiskusi dengan guru kelas untuk meminimalisir kelemahan-kelemahan tersebut. Penilaian siklus II pada pertemuan ketiga digambarkan melalui grafik berikut:
rekapitulasi
penilaian
penerapan
pembelajaran
olahraga
untuk
meningkatkan aktivitas fisik anak-anak
autis di Taman Kanak-kanak digambarkan melalui grafik berikut:

Grafik 2. Penilaian siklus II penerapan aktivitas fisik anak-anak autis melalui pembelajaran olahraga di Taman Kanak-kanak.

Penelitian mulai dari prasiklus, siklus I dan siklus II terjadi peningkatan dalam peningkatan aktivitas fisik anak-anak autis, rekapitulasi penilaian dari prasiklus, siklus I dan siklus II terlihat pada Tabel 1 berikut ini:

Tabel 1. Rekapitulasi penilaian penerapan pembelajaran olahraga untuk meningkatkan aktivitas fisik anak-anak autis di Taman Kanak-kanak.

\begin{tabular}{|l|c|c|c|}
\hline \multicolumn{1}{|c|}{ Kategori } & $\begin{array}{c}\text { Pra } \\
\text { siklus } \\
(\%)\end{array}$ & $\begin{array}{c}\text { Siklus I } \\
(\%)\end{array}$ & $\begin{array}{c}\text { Siklus } \\
\text { II (\%) }\end{array}$ \\
\hline $\begin{array}{l}\text { BB (Belum } \\
\text { Berkembang) }\end{array}$ & 9 & 89 & 11 \\
\hline $\begin{array}{l}\text { MB (Mulai } \\
\text { Berkembang) }\end{array}$ & 0 & 4 & 67 \\
\hline $\begin{array}{l}\text { BSH } \\
\text { (Berkembang } \\
\text { Sesuai } \\
\text { Harapan) }\end{array}$ & 0 & 0 & 33 \\
\hline $\begin{array}{l}\text { BSB } \\
\text { (Berkembang } \\
\text { Sangat } \\
\text { Bagus) }\end{array}$ & 0 & 0 & 0 \\
\hline
\end{tabular}

Dari tabel 1 diatas didapatkan bahwa aktivitas fisik anak-anak autis melalui pembelajaran olahraga dari prasiklus, persentase anak belum berkembang menurun dari $89 \%$ menjadi $11 \%$. Anak yang mulai berkembang meningkat dari $4 \%$ menjadi $67 \%$. Anak yang berkembang sesuai harapan meningkat menjadi 63\%. Secara lebih jelas,
Grafik 3. Penilaian rekapitulasi penerapan pembelajaran olahraga untuk meningkatkan aktivitas fisik anak-anak autis di Taman Kanak-kanak.

Berdasarkan grafik 3 diatas terlihat penelitian pada pra siklus, siklus I dan siklus II terjadi peningkatan aktivitas fisik anak-anak autis di Taman Kanakkanak melalui pembelajaran olahraga. Penelitian tahap awal dilakukan melalui siklus 1. Pada penelitian pra siklus diperoleh nilai dengan hasil 24 orang anak belum berkembang dan 1 orang anak mulai berkembang. Dikarenakan hasilnya belum memenuhi kriteia penilaian, maka dilanjutkan ke siklus II untuk memperbaiki perencanaan di siklus I. Dari penelitian siklus ke II didapatkan hasil yang signifikan 3 orang anak belum berkembang.

Jika dipersentasekan diperoleh nilai sebesar $67 \%$ anak sudah berkembang sesuai harapan dari $4 \%$ di tahap sebelumnya. Dari persentase tersebut diakumulasikan terjadi peningkatan rata-rata sebesar $63 \%$.

Latihan-latihan olahraga akuatik dan keterampilan bermain yang dapat dilakukan oleh anak autis sebagai berikut: a. Tendangan kaki saat duduk di pinggiran kolam renang; $b$. Tendangan kaki dengan posisi badan di pinggiran kolam renang; c. Berjalan di depan kolam renang; d. Ular-ularan bermain kelompok; e. Mengayuh dalam posisi terlentang di atas air; $f$. Melompat berpasangan seperti kanguru melompat; g. Jogging lambat; h. Gaya bebas berenang dengan posisi berdiri di air; i. Bermain flap di air; j. Lemparkan bola ke dalam cincin bergerak (Yusnira, 2015). 


\section{JURNAL CERIA}

ISSN : 2614-6347 (Print) 2614-4107 (Online)

Vol.1 $\mid$ No.3 1 Mei 2018

Ketahanan kardiovaskular dan otot harus dikembangkan pada anak-anak dengan autis yang berusia antara 6 dan 8 tahun. Berbagai kegiatan olahraga untuk anak-anak ini seperti berlari, naik sepeda, kegiatan keseimbangan (berputar dan berjalan di jalur), permainan air, berenang, berjalan, naik sepeda stasioner, sepeda dua roda atau tiga roda, pelacakan, menari, dan menggunakan trampolin (Auxter, Pyfer, \& Huettig, 2001; Lerner, 2007; Menear \& Smith, 2008; Moor, 2008).

\section{SIMPULAN}

Berdasarkan penelitian dan pengamatan langsung terhadap anak-anak autis dalam penerapan pembelajaran olahraga untuk meningkatkan aktivitas fisik anak-anak autis di Taman Kanak-kanak Luthfiyyah Kabupaten Bandung Barat, maka dapat disumpulkan bahwa terjadi peningkatan aktivitas fisik anak-anak autis di Taman Kanak-kanak melalui pembelajaran olahraga sebesar $63 \%$.

Anak diharapkan mampu meningkatkan aktivitas fisiknya secara berkelanjutan serta dapat lebih menyehatkan anak tersebut. Aktivitas fisik melalui pembelajaran olahraga membuat anakanak autis menjadi antusias karena anak pada umumnya sangat menyukai aktivitas bergerak. Dengan arahan guru, anak bergerak dan melakukan aktivitas fisik terstruktur dan baik.

Pembelajaran olahraga sangat baik diterapkan dalam meningkatkan aktivitas fisik anak-anak autis di Taman Kanak-kanak. Pembelajaran olahraga untuk anak-anak autis menjadi bagian terpenting dalam meningkatkan aktivitas fisik mereka. Anak dengan bebas dapat mengembangkan semua gerak tanpa dibatasi.

\section{REFERENCES}

Arikunto, S. (2009). Evaluasi Program
Pendidikan Pedoman Teoritis Bagi

Mahasiswa dan Praktisi

Pendidikan. Jakarta: Bumi Aksara.

Arikunto, S. (2010). Prosedur

Penelitian Suatu Pendekatan

Praktek. Jakarta: PT. Rineka Cipta.

Association, A. P. (2000). Diagnostic and Statistical Manual of Mental Disorders (4th ed.). Washington, DC: American Psychiatric Association.

Auxter, D., Pyfer, J., \& Huettig, C. (2001). Principles And Methods of Adapted Physical Education And Recreation. New York: McGrawHill.

Bryson, S. E., Bradley, E. A., Thompson, A., \& Wainwright, A. (2008). Prevalence Of Autism Among Adolescents With Intellectual Disabilities. The Canadian Journal of Psychiatry, 53, 449-459.

Doyle, B. T., \& Iland, E. D. (2004). Autism Spectrum Disorders From A To Z. Texas: Future Horizons.

Firmansyah, D. (2018). Analysis Of Language Skills In Primary School Children (Study Development Of Child Psychology Of Language). PrimaryEdu - Journal of Primary Education, 2(1), 35-44. https://doi.org/10.22460/pej.v1i1.6 68

Kurtz, L. A. (2008). Understanding Motor Skills in Children with Dyspraxia, ADHD, Autism, and Other Learning Disabilities. London: Jessica Kingsley Publishers.

Lerner, B. S. (2007). Working With School-Age Children And Adolescents. New York: Guildford 


\section{JURNAL CERIA}

ISSN : 2614-6347 (Print) 2614-4107 (Online)

Vol.1 I No.3 | Mei 2018

Publications.

Marta, R. (2017). Penanganan Kognitif Down Syndrome melalui Metode Puzzle pada Anak Usia Dini. Journal Obsesi (Journal of Early Chilhood Education, 1(1), 32-41.

Menear, K. S., \& Smith, S. (2008).

Physical Education For Students With Autism. Teaching Exceptional Children, 40, 32-37.

Moor, J. (2008). Playing, Laughing and Learning with Children on the Autism Spectrum: A Practical Resource of Plat Ideas for Parents and Carers (2nd ed.). London: Jessica Kingsley Publishers.

Sudjana, N. (2009). Penilaian Hasil Proses Belajar Mengajar. Bandung: Remaja Rosdakarya.

Sugiyono. (2008). Metode Penelitian Pendidikan. Bandung: Alfabeta.

Yanardag, M., Yilmaz, I., \& Aras, O. (2010). Approaches to the teaching exercise and sports for the children with autism. International Journal of Early Children Special Education. INT-JECSE, 2(3), 214230.

Yusnira. (2015). Pengelolaan Pembelajaran melalui Bermain Pasir dan Air pada Sentra Bahan Alam di PAUD Insan Kamil Bangkinang Kampar. Journal Obsesi (Journal of Early Chilhood Education, 1(2), 79-86. 